\title{
Attachment to Certain Natural Environments: A Basis for Choice of Recreational Settings, Activities and Restoration from Stress?
}

\author{
Anna A Adevi \\ Department of Work Science, Business Economics and Environmental Psychology \\ PO Box 88, Swedish University of Agricultural Sciences \\ SE 23053 Alnarp, Sweden \\ Tel: 46-40-415-415Ｅ-mail: anna.a.adevi@slu.se \\ Patrik Grahn (Corresponding author) \\ Department of Work Science, Business Economics and Environmental Psychology \\ PO Box 88, Swedish University of Agricultural Sciences \\ SE 23053 Alnarp, Sweden \\ Tel: 46-40-415-425Ｅ-mail: patrik.grahn@slu.se
}

\author{
Received: September 16, $2011 \quad$ Accepted: October 13, $2011 \quad$ Published: December 1, 2011 \\ doi:10.5539/enrr.v1n1p36 \\ URL: http://dx.doi.org/10.5539/enrr.v1n1p36
}

The project is sponsored by The National Board of Housing, Building and Planning, The Swedish National Institute of Public Health. The National Board of Health and Welfare, The Swedish Association of Local Authorities and Regions, The Swedish Environmental Protection Agency, The Swedish National Heritage Board, The Swedish Board of Agriculture and The Swedish Forest Agency (Sponsoring information)

\begin{abstract}
Studies suggest that people's choice of recreation depends on attachment to certain places. Others indicate that recreation in nature restores people from stress. Could it be that during childhood people become more attached to certain types of environments, and are more restored after performing recreation in these environments?

The results are based on a questionnaire sent out at random to 2,000 people in Sweden, and show that people feel more at home in the type of landscape they grew up in, and that this has importance in their choice of recreational setting as well as the recreational activity they choose. An association was also found between people's levels of stress and how often they take part in recreation in natural settings where they feel most at home.

The phenomenon "feeling at home in certain natural environments" could be an important factor in discussing landscape planning, nature and restoration from stress.
\end{abstract}

Keywords: Landscape characteristics, Preferences, Restorative environments, Recreation, Outdoor activities

\section{Introduction}

A wide variety of literature on recreational needs has been presented (e.g. Csikszentmihalyi, 1975; De Grazia, 1962; Iso-Ahola, 1980; Manning, 1999) since the early 1960s. Prominent among the theories is the notion that recreative environments and activities should entail restoration from labour and stress, and moreover should develop the individual by involving and absorbing him/her in something of great importance. An increasing number of research findings have also indicated that recreation in natural environments can bring about a quick and strong recovery in stressed individuals (e.g. Nilsson et al., 2011). And the links between natural landscapes and health are continuously recognized, as seen in the emergence of new studies on the ameliorating effects of exposure to green spaces on stress levels (e.g. Annerstedt et al., 2010). According to the European Landscape Convention, natural landscapes are a key factor in individual as well as social well-being (Landscape Convention, 2000). Nevertheless, Velarde, Fry, and Tveit (2007) observe that the environment in different health studies is 
classified as either "nature" or "urban", and that there is a lack of studies using subcategories of these main categories or perhaps other general aspects or characteristics of the environment. Recent studies provide a more nuanced relationship between nature and health: findings indicate that some particular characteristics of nature are more efficient for stress recovery, such as species richness (Grahn \& Stigsdotter, 2010); and broadleaved forests seem to be more restorative than coniferous forests (Annerstedt et al., 2010). In addition, these studies indicate that different human attributes are important in explaining the outcome. That is, people's needs may differ depending on aspects such as sex.

Empirical studies concerning outdoor recreation have traditionally focused on activities (Morgan \& Messenger, 2009), but there are comparatively few on the relationship between recreational activities and choice of recreation environments, particularly the relationship to health. In the 1980s some researchers argued that an optimal experience of recreation, leading to satisfaction, results from specific activities being accomplished in certain settings (Driver, Brown, Stankey, \& Gregoire, 1987). And in his studies of relationships between people's choice of activity type and setting in outdoor recreation areas, Grahn (1991) claimed that the connections he found could be interpreted as suggesting that people want to be involved in the setting as well as in the activities. More recent research projects have also been conducted to document a setting-activity-experience relationship (e.g. Pierskalla, Lee, Stein, Anderson, \& Nickerson, 2004). In the early 1990s some researchers claimed that the most restorative experiences were connected to nature-related activities such as walking, hiking and boating in nature environments (e.g. Cimprich, 1993), and these studies have received more recent support (Bodin \& Hartig, 2003; Sugiyama \& Ward Thompson, 2007). However, some recent studies (e.g. Ottosson \& Grahn, 2008) suggest that human characteristics are important in explaining the outcome; i.e., people's needs differ, depending on their background or history such as health.

Increasingly, involvement has become a key factor in research on recreation (as suggested by e.g. De Grazia, 1962). Involvement, it has been claimed, affects people's motives for recreation, choice of activity type and setting, and not least how satisfied they are with their recreation (Gross \& Brown, 2008). In turn, involvement has been argued to consist of place attachment (e.g. Gross \& Brown, 2008; Kyle, Graefe, Manning, \& Bacon, 2003; Morgan \& Messenger, 2009), significant in explaining motivations for outdoor recreation. Moreover, place attachment is asserted to be associated with the quality of the resulting recreation experience and restoration. However, to our knowledge the link between involvement, place attachment, recreation activities and human health has not been studied thus far.

Attachment Theory is primarily based on ethological theories of animal imprinting, which means that all species have innate behavioural systems that have contributed to the species' survival during evolution (Bowlby, 1969). The theory entails that parent and child are biologically predetermined to create related links. This attachment between parent and child is important throughout life and is based on trust or non-trust (Bowlby, 1980). The basis of Bowlby's theory is that humans have a targeted and instinctual behaviour. This means that they adapt to their surroundings similarly to how animals do. Since the 1980s, Attachment Theory has been broadened to include physical environments to become the concept of place attachment (Low \& Altman, 1992).

Related to place attachment is the concept of affordance (Adevi \& Grahn, in press; Grahn, Tenngart Ivarsson, Stigsdotter, \& Bengtsson, 2010; Pierskalla et al., 2004). Affordances tell you, by instinct or by experience, which activities are best suited to implement in certain environments. The concept was put forward by Gibson (1979), maintaining that the environment offers something good or bad to each individual. Gibson argues that action and perception are closely linked, and that environments offer special forms of information concerning possibilities for action linked to different species and individual beings. Moreover, he maintains that people's perceptions concerning affordances are immediate and direct, and relate to functioning in a given environment - that perception concerns action in a certain context. A path in nature is perceived because the surface announces that it is possible to walk there. People do not first perceive colours and texture; they perceive affordances regarding safety, for instance, and nature is believed to be particularly rich in affordances (Gibson, 1979). Thus, experiences - better or worse - would immediately and directly be related to specific activities in a special setting.

In his doctoral dissertation, Hjort (1983) claimed that people long for places where they feel at home. This "feeling at home", he argued, is associated with places where people grew up. Some researchers conclude that it is during childhood and adolescence that people develop the capacity to handle different affordances and to make themselves familiar with them (e.g. Heft, 2010); this is reminiscent of place attachment. Environments that contain affordances that signal trust are perhaps likely to become more connected to a child. Adevi and Grahn (in press) also found that characteristics in a landscape, which induced a "feeling at home", could be connected to characteristics of the landscape where a person had grown up. THIS WAS INTERPRETED FROM THE theory 
of place attachment. Among the public in general, the German concept of Heimat is often - and unfortunately associated with National Socialism (Blickle, 2004). However, the concept is much older than this political movement and has many humanistic connotations which not at all are political (Applegate, 1990). The word is used in everyday life in Austria, Germany and Switzerland, and can e.g. represent an old family farm (Blickle, 2004). Amongst others, the concept involves languages, culture, tradition and habits, all of which are linked to a certain geographical district: that people are bound to their Heimat by their birth, their childhood and their earliest experiences (Blickle, 2004). The core of Heimat can be said to consist of attachment processes to a particular place, generally in rural settings. Heimat is strongly connected to an admiration of nature and rural landscapes (Applegate, 1990). "Let us again consider the essence of Heimat. Heimat is based in a spatial conception of identity" (Blickle, 2004, p.15). Many studies also show that people who move to a new area carry with them preferences from the region where they grew up (Kaups, 1995; Noble, 1992; Ward \& Styles, 2007). In fact, people deeply mourn their childhood landscape (Ward \& Styles, 2007, p. 2-3). For example, Finnish emigrants who moved to the United States in the 19th century settled in areas with great coniferous forests, many lakes and cold Nordic weather, even though they could have doubled their crop yields if they had settled in more fertile southern areas, which were also available. In addition, those who had to settle in an area very different from that in which they had grown up often began to change the landscape of the new area so that it resembled the former one (Loukinen, 1996; Paasi, 1997).

Bell (1999) suggests that what the environment offers in terms of affordances is important to a person, concerning which activities are appropriate, how he/she should behave, and not least his/her health and well-being. Grahn et al. (2010) described how people were rehabilitated from stress-related mental disease at a rehabilitation garden. They found that a person suffering from stress cannot manage too many impressions that are difficult to sort out and respond to; they react to these impressions as they would to a threat. Instead, simple and familiar affordances could be experienced as something secure; something they could trust and rely on (Grahn et al., 2010).

We presume that place attachment involves "familiar affordances", whereby people are also better restored from stress. We suppose that this is the case because they feel safer and more secure in these environments.

Research thus far indicates that:

Recreation in natural environments is beneficial to people's health (Nilsson et al., 2011).

Nature-related activities in natural environments are beneficial to people's health (Sugiyama \& Ward Thompson, 2007).

People's choice of recreation, and not least their satisfaction with the recreational experience, depends on place attachment (Gross \& Brown, 2008).

People's needs differ depending on their personal characteristics or history. These attributes are relevant concerning associations between outdoor recreation (activities as well as settings) and health benefits (Annerstedt et al., 2010; Ottosson \& Grahn, 2008).

Could it be that during childhood people become more attached to certain landscape types and activities associated with that type of landscape, resulting in their being more restored after performing outdoor activities in landscapes they are attached to? To our knowledge, no study has yet been undertaken to answer these questions.

\section{Aims and objectives}

Our hypothesis can be divided into two parts:

First: We presume that people become attached to a certain landscape type during childhood and adolescence, and accordingly also to outdoor activities suitable to this landscape type. This implies that they primarily want to take part in recreation in the type of environment they have become attached to, and perform outdoor activities associated with this type of environment.

Second: We presume that people are better restored from high stress levels if they can engage in outdoor activities in environments they have become attached to.

The aim of the study was to investigate whether:

- people who feel at home in particular types of landscapes more often visit nature areas associated with that type of landscape, and perform certain outdoor activities more often

- certain outdoor activities and nature areas are significantly connected to people's level of stress 
- associations can be found between feeling at home in particular types of landscapes, nature areas and outdoor activities on the one hand and people's level of stress on the other

Our goal was to obtain information on citizens':

- $\quad$ background in terms of sex, age and socioeconomic status (SES)

- $\quad$ home environment - landscape type, current home address and address during childhood

- $\quad$ the "feeling of being at home" in different landscape types

- $\quad$ information on how often people perform certain outdoor activities

- $\quad$ information on how often people visit certain nature areas

- $\quad$ self-estimation of stress-related complaints,

as well as to determine whether there are any statistical relationships between the above-mentioned factors.

\section{Materials and methods}

\subsection{Landscape types}

This study was carried out in Sweden. The country was divided into six main landscape types (forest, mountains, coast, agricultural plains, pasture and lakes), following the National Atlas of Sweden (Sveriges Nationalatlas, 1996) and Statistics Sweden (Statistical Yearbook of Sweden, 2009). These main types of landscapes are most often quite homogenous regions and include urban areas. They also consist of some important discrete pockets of other landscape types, e.g. agricultural plains and pasture in forest environments. The intent was to compare our data with this classification (figures below from the Statistical Yearbook of Sweden 2009 if no other reference is mentioned). The total area is dominated by forests (53\%), and mountains also take up a large surface area (12\%). The population is most often sparsely scattered in these areas. Moreover, the country has a large number of lakes ( $9 \%$ of the area), with 23 lakes larger than 100 square kilometres. Most of these larger lakes are situated just below the mountain regions in the north, but the four largest lakes are found in the southern part of the country. Cultivated plains $(8 \%)$ and pasture land (7\%) take up a relatively small area compared with other European countries, and these areas are most often situated in the southern part of the country. The coast is relatively long: $2400 \mathrm{~km}$, and $7600 \mathrm{~km}$ if all creeks and bays are included. The coastal area is considered to comprise about $7 \%$ of the total surface of Sweden (Boverket, 2006). These areas are relatively densely populated. Larger towns $(>100,000$ inhabitants) are most often situated on the coast or the largest lakes. Some of the larger towns are also situated on the plains and in the forested areas. The remaining $4 \%$ consists of indistinct landscape, consisting of a mixture of, e.g., swamps, stony land and brushwood.

\subsection{Public survey}

We assigned Statistics Sweden with obtaining a representative sample of people born in and living in Sweden, and they performed the task by sending questionnaires to a randomized sample of Swedish citizens. The questionnaires were sent by mail to randomly selected individuals aged 18-100 years. A total of 2,000 questionnaires were sent and 1,988 were successfully delivered. A total of 1,325 completed or nearly completed questionnaires were returned; the response rate was thus $67 \%$. The oldest respondent was 93 years old, the youngest 18 . The respondents were asked to state the exact address they considered to be their address during childhood and adolescence. Statistics Sweden carried out the coding of their present address, as well as their address during childhood. The survey was carried out in the form of a mailed questionnaire with pre-coded questions, most often with multiple-choice options, however with the possibility to make individual remarks.

We associated the respondents' background data concerning addresses (current as well as during childhood and adolescence) with the six main landscape types. Following the National Atlas of Sweden (Sveriges Nationalatlas, 1996), most of the country's municipalities can be connected to a certain type of landscape. In doubtful cases when we found respondents near boundaries between different types of landscapes (in 16 of 290 municipalities), someone with expertise in the respective municipality was contacted to determine an assignment. All the respondents' addresses (present as well as from childhood) could be connected to one type of landscape. A total of 823 respondents have moved to another region or city than the one they grew up in.

An examination of the respondents' profiles showed that the distribution of socio-demographic data is representative of the general situation in Sweden. This means that no statistically significant deviation existed with regard to socio-economic grouping (SES), sex or age between the material received and the material one could expect (Statistical Yearbook of Sweden 2009). SES classification follows Statistics Sweden (Swedish Socioeconomic Classification Reports on Statistical Co-ordination, 1995). 


\subsection{Perceived health state}

In order to measure the respondents' perceived health state we used a set of self-assessment questions. Several different validated instruments are used worldwide for measuring self-perceived health, all of which demand the individual's personal and subjective experience of health status. For estimating a population's stress level, a frequently used test in Sweden is the SCI-93, developed by Nyström and Nyström $(1995,1996)$. This test contains 35 questions concerning stress symptoms in terms of mental, muscular and autonomic complaints (problems with eating, sleeping, etc.). Grahn and Stigsdotter (2003) identified the most prominent and clear questions in the SCI-93, and these were chosen to achieve a simplified but relevant subset of questions to measure perceived stress. The chosen questions concerned headache, pain in the nape of the neck, common cold, irritation, fatigue, backache and stress. The association between these seven complaints was examined using factor analysis. The three complaints of irritation, fatigue and stress formed a strong factor, interpreted as perceived Level of Stress (LS). To ensure that these three variables weighed fairly in the new variable LS, the values were multiplied by the principal component value (PCA) according to the formula (PCAirritation $\mathrm{x}$ irritation $)+($ PCAfatigue $\mathrm{x}$ fatigue $)+($ PCAstress $\mathrm{x}$ stress $)=$ LS (Manly, 1994). This self-assessment LS test (including the technique of weighting by PCA values) has been used in other studies (Annerstedt et al., 2010; Grahn \& Stigsdotter, 2010; Nordh, Grahn, \& Währborg, 2009). In the study by Annerstedt et al. (2010), the LS instrument was tested regarding validity in relation to other self-assessment instruments with reference to perceived health, and was found to be reliable and valid. We applied this simplified instrument in this study and have used the same procedure as Annerstedt et al. (2010).

\subsection{Perceptions of home landscape}

The questionnaire included the question: "In which landscape do you feel most at home? State one or more alternative(s). Landscapes dominated by: 1. Agricultural plains, 2. Forested areas, 3. Lakes, 4. Pasture and grazing land, 5. Coast and seaboard, 6. Mountains." These alternatives correspond to the main landscape types in Sweden. We performed a Factor analysis (Promax oblique rotation) to examine whether there was an association between "feeling at home" in these six different landscape types. From the variables that were strong in the factor analysis (factor loading >.50), new variables (landscape types) were constructed. We found four factors derived from the six items, interpreted as four categories of landscape (Adevi \& Grahn, in press). They were named after included variables with factor loadings $>.50$ in each factor: Forested areas (consisting of one variable); Coast and seaboard (consisting of one variable); Rolling hills and lakes (consisting of two variables $>.50$ - Mountains and Lakes); and Agricultural plains (consisting of two variables $>.50$ - Agricultural plains and Pasture and grazing land). Again, to ensure that the different variables weighed fairly in the new variable, the values were multiplied by the principal component value (PCA) according to the formula: (PCAlandscape $1 \times$ landscape 1) + (PCAlandscape 2 x landscape 2) = Landscape type (Manly, 1994). In connection with this analysis, we also combined people's home landscapes into four different types. In our sample, 426 respondents live in landscapes dominated by forests, 386 in landscapes dominated by the coast, 285 in landscapes dominated by rolling hills and lakes and 228 in landscapes dominated by agricultural plains.

The respondents' answers were statistically analysed using the statistical software SAS (SAS Statistics, 2009).

\section{Results}

In order to test the hypotheses and answer the specific research questions, a number of analyses and interpretations will be presented below.

\subsection{Associations between landscapes visited and familiarity}

Question A (see appendix): "How often have you visited these areas in the past twelve months?" Following this question was a list of five different types of outdoor areas. Respondents could choose between the following alternatives: $>3$ times/week, 1-3 times/week, 1-3 times/month, 1-6 times/year and Never. We recoded the five response alternatives to numbers estimating how often they visited the different types of recreation area (208, $104,24,3,0)$. "More than three times a week" was recoded to "four times a week", and the other alternatives were recoded from the midpoints. We performed a MANOVA analysis (SAS GLM) between the type of landscape the respondent feels at home in (independent) and how often they visit different kinds of recreation areas (outcome), adjusted for potential confounders (sex and SES).

All five types of natural areas were frequently visited for excursions, which were of the same magnitude. Through MANOVA analysis of the 1,325 respondents (Table 1), we found strong positive associations between people's visits to the recreational areas and the type of landscape in which the respondents felt at home. For instance, people who feel at home in landscapes dominated by forests visit natural areas without facilities for 
outdoor recreation more often $(\mathrm{p}<0.0001)$, while people who feel at home in landscapes dominated by coasts visit sea beaches or the archipelago more often $(\mathrm{p}<0.0001)$.

Table 1 also shows that people who have moved from their childhood region follow the same pattern. Hence, people who have moved and feel at home in landscapes dominated by forests visit natural areas without facilities for outdoor recreation more often $(\mathrm{p}<0.0001)$, while people who have moved and feel at home in landscapes dominated by coasts visit sea beaches or the archipelago more often $(p<0.0001)$. The MANOVA test shows an overall effect concerning associations between "feeling at home in a certain type of landscape" and "visits to different types of recreation areas", except for people who feel at home in the agricultural plains. This result also applies to those who have moved from their childhood region. People's socio-economy did not affect any relationship. However, visiting a "beach/bathing place at the lake or sea" was significantly associated with people's gender, and this relationship concerned all landscape types: women visit these recreation areas more often. In spite of this, we found that people who feel at home in landscapes dominated by coasts more often visit beaches/bathing places at the lake or sea.

\subsection{Outdoor activities}

Question B (see appendix): "Have you practised any of the following outdoor activities in the past 12 months? If yes, how often?" Following this question was a list of 28 outdoor activities. Respondents could choose between the following four alternatives: $>3$ times/week, 1-3 times/week, 1-3 times/month and 1-6 times/year. We recoded the four response alternatives to numbers estimating how often they visited the recreation areas $(208,104,24,3$ and " 0 " if they did not fill in any alternative). We performed a $T$-test analysis between the type of landscape the respondent feels at home in (independent) and the 28 single activities (outcome).

The most frequently performed outdoors activities were walking/rambling, followed by resting/relaxing, enjoying the natural environment, gardening, cycling and going outside to be by myself. We investigated the frequency of single outdoor activities, broken down by type of landscape one feels at home in, and found the following (T-test, not shown).

T-test: People who feel at home in landscapes dominated by one landscape type versus people who feel at home in another landscape type.

(1). Feel at home in forests: Activities performed more often: Hunting $(\mathrm{p}<0.0001)$, walking/rambling $(\mathrm{p}<0.001)$, cross-country skiing $(\mathrm{p}<0.01)$, picking mushrooms $(\mathrm{p}<0.01)$ and enjoying nature $(\mathrm{p}<0.01)$. Activities performed less often: Going out and having a look at people $(p<0.001)$, bathing in the lake or sea $(p<0.001)$, boating $(\mathrm{p}<0.01)$, cycling $(\mathrm{p}<0.01)$ and taking photos $(\mathrm{p}<0.05)$.

(2). Feel at home in coasts: Activities performed more often: Jogging $(\mathrm{p}<0.001)$, boating $(\mathrm{p}<0.001)$, bathing in the lake or sea $(\mathrm{p}<0.01)$, cycling $(\mathrm{p}<0.05)$, looking at views $(\mathrm{p}<0.05)$ and sunbathing $(\mathrm{p}<0.05)$. Activities performed less often: Picking berries ( $p<0.001)$, hunting ( $<<0.01$ ), picking mushrooms $(p<0.01)$, going out to be by myself $(\mathrm{p}<0.01)$ and gardening $(\mathrm{p}<0.05)$.

(3). Feel at home in rolling hills and lakes: Activities performed more often: Going on outings with family and friends ( $\mathrm{p}<0.001)$, sunbathing $(\mathrm{p}<0.01)$, boating $(\mathrm{p}<0.01)$, downhill skiing $(\mathrm{p}<0.05)$, hiking and camping in tents $(\mathrm{p}<0.05)$ and golfing $(\mathrm{p}<0.05)$. Activities performed less often: Going out to be by myself $(\mathrm{p}<0.01)$ and going out and having a look at people $(\mathrm{p}<0.05)$.

(4). Feel at home in agricultural plains: Activities performed more often: Gardening $(\mathrm{p}<0.0001)$, enjoying cultural environments $(\mathrm{p}<0.01)$ and going out to be by myself $(\mathrm{p}<0.05)$.

Since we could not perform a factor analysis (Kaiser's Measure of Sampling Adequacy was too low) we performed a Cluster analysis (Varclus disjoint oblique principal component cluster analysis with orthoblique initialization) to find similarities between activities carried out by our respondents. We clustered the activities across all people who answered the questionnaire. This cluster analysis is divisive; that is one starts at the root (one cluster) and recursively splits the clusters. The cluster analysis stops when no cluster meets the default criterion for splitting (when each cluster has only a single eigenvalue greater than one). The various outdoor activities are merged into different clusters, depending on how often and in which combinations they have been implemented by the respondents. These clusters have been renamed as activity types. The new variables (activity types) were established using the formula (Activity $1 \ldots+$ Activity $\mathrm{n}$ ) $/ \mathrm{n}=$ Activity type.

Table 2 shows the result of the cluster analysis of the 28 activities. The optimal solution, when no cluster met the criterion for splitting, was ten clusters. 
The cluster analysis brought together activities with common content, such as downhill skiing, cross-country skiing and skating. Hence, they were often very easy to interpret. The first cluster consists of the activities picking berries (blueberries, wild raspberries, etc.), picking mushrooms, going fishing, and going hiking and camping in a tent. These activities are associated with a more untouched and wild nature: Wilderness activities. The second cluster contains activities in which contact with friends and family members is important: Social activities. The seventh cluster contains seven activities, and the activity going out to be by myself suggests wanting to be alone with the experience of nature, undisturbed; possibly to be more attentive to what happens there. When photographing natural phenomena or hunting, it is important not to lose one's attention. A dog may be able to help people discover phenomena in nature. This cluster is about more individual and focused activities in nature: Individual experiences in nature.

The most common activity types are taking walks in nature, followed by sun and bathing, social activities, jogging and cycling, and gardening and culture. To explore which of the activity types are most associated with the landscape people feel at home in, we performed a MANOVA analysis type III, in which each of the activity types was put last into the model: the type of landscape the respondent feels at home in (independent) and the activity types (outcome), adjusted for potential confounders (sex and SES).

Table 3 shows that the relationship between type of activity and feeling at home in a landscape dominated by forests primarily concerns taking walks in nature and wilderness activities, while these are in the reverse order for those who have moved. For the latter, the relationship is negative in relation to social activities and boating and view. The relationship is strong between people who feel at home in coastal areas and the activity types boating and view, jogging and cycling, and sun and bathing. That is, they more often perform these activities. The relationship is negative concerning wilderness activities. We find strong positive associations between taking walks in nature and feeling at home around rolling hills and lakes. The relationship is also significant with boating and view, but not for those who have moved: People who have moved away from rolling hill landscapes tend to favour winter sports. People who feel at home in the agricultural plains more often carry out gardening and culture. The MANOVA test shows an overall effect concerning associations between "feeling at home in a certain type of landscape" and "outdoor activity types". This result also applies to those who have moved from their childhood region. People's socio-economy did not affect any relationship. However, "sun and bathing" and "taking walks in nature" were significantly associated with people's gender, and this relationship concerned all landscape types: women perform these activities more often. In spite of this, we found that people who feel at home in landscapes dominated by coasts more often perform "sun and bathing", and people who feel at home in landscapes dominated by forests or rolling hills and lakes more often take walks in nature.

\subsection{Level of stress}

Question C: "During the past 12 months, how often have you suffered from:" Following this question was a list of seven complaints. The respondents could choose between seven response alternatives: Never, Very occasionally, At most once quarterly, At most once monthly, At most once a fortnight, At most once weekly, and Practically every day. We recoded the answers to numbers estimating how often they suffered from each complaint per year $(0,2,4,12,26,52,365)$, where "Very occasionally" was recoded to "Twice a year". In accordance with the procedure by Grahn and Stigsdotter (2003) (and Annerstedt et al., 2010; Grahn \& Stigsdotter, 2010; Nordh et al., 2009), we performed a Factor analysis - Promax oblique rotation to examine whether there was an association between the different complaints, and a Principal Component Analysis based on the correlation matrix to examine the relative contribution of the variance in $L S$ by the included complaints. Kaiser's Measure of Sampling Adequacy was performed, testing the applicability of factor analysis. We weighed the included variables in the new variable using principal components (Manly, 1994).

Factor analysis shows that Kaiser's measure of sampling adequacy was 0.80 , and indicates two clearly distinguishable factors with eigenvalues $>1$. The first factor explains $48 \%$ of the variation, the second $35 \%$ (Table 4). The table shows that three complaints have high factor loadings in the first factor: irritation, stress and fatigue. These three variables together pointed to one strong factor that was interpreted as level of stress. A new variable, level of stress $(L S)$, could thereby be calculated. The first principal component explained $65 \%$ of the variation and the non-rotated principal component values $(P C A)$ were $0.77,0.75$ and 0.78 , respectively. With the aid of these values we were able to make a fairly weighed calculation of $L S$ (Annerstedt et al. 2010; Manly, 1994).

Through T-test analysis we found that level of stress was $14 \%$ higher in women than men $(\mathrm{p}<0.001)$ and that the levels were highest in both men and women aged 18-45, with a peak at about 27 years of age. 


\subsection{How important are time spent in outdoor green spaces for level of stress?}

Question D: "How long do you, on average, stay in the recreation area per visit?" The respondents could choose between the following alternatives: 15-30 minutes; 30-60 minutes; 1-2 hours; 2-3 hours and $>3$ hours. We recoded the five response alternatives to numbers estimating how long $(22,45,90,150$ or 240 minutes) they spent at the recreation areas. "More than three hours" was recoded to "four hours" - or 240 minutes - and the other alternatives were recoded from the midpoints. We performed a Pearson correlation analysis between LS and the number of occasions on which people visit natural areas and the amount of time they stay there. Moreover, we performed an ANOVA analysis between LS and number of visits to recreation areas time spent at recreation areas and socio-economic grouping (SES).

Through correlation analysis (not shown) we found that LS correlates significantly with both the number of occasions on which people visit natural areas $(p<0.01)$ and the times they visit the spaces $(p<0.01)$. That is: since the correlation is negative, the more often, and the more time people spend in natural areas, the lower the stress levels. Through ANOVA analysis we found that the time people spend in outdoor settings each time they visit natural areas is most associated with a lower stress level (Table 5).

\subsection{Associations between level of stress and recreation activities}

We performed an ANOVA analysis in which LS was the dependent variable and the activity types were independent variables, broken down into the four types of feeling at home in different landscapes, adjusted for potential confounders (sex and SES).

The result of the ANOVA analysis (Table 6) shows that individual experiences in nature seem to lower the stress levels most, but not for people who have moved from landscapes dominated by forests, coasts, and rolling hills and lakes. For them, wilderness activities seem to lower stress levels more. Winter sport also seem to lower stress levels (except for people who feel at home in rolling hills and lakes), but not for those who have moved from landscape types where they feel at home. Gardening and culture are important in producing lower levels of stress for people who feel at home in landscapes dominated by agricultural plains and rolling hills and lakes. Moreover, taking walks in nature and boating and view are important in producing lower levels of stress for people who feel at home in landscapes dominated by coasts; however, boating and view is not important for people who have moved from landscapes dominated by coasts.

\subsection{Associations between level of stress and recreational habits}

To investigate whether people who feel at home in a certain type of landscape and who suffer from stress perform particular activities at specific recreation areas, we first combined each activity type with each of the five recreation areas (activity type * recreation area). Five types of nature areas and ten types of activities resulted in 50 combinations. We performed a Regression analysis (R-square stepwise selection with Mallows $\mathrm{C}(\mathrm{p})$ for optimal solutions) to investigate which combination of activity type and nature area distinguishes the lowest levels of stress in people who feel at home in different landscape types. The lowest Mallows $\mathrm{C}(\mathrm{p})$ in an analysis shows an optimal congruence between use of activity type/nature area and a low level of stress (not shown). Model: LS=Nature area/Activity type 1; Nature area/Activity type 2; ... Nature area/Activity type 50.

(1). People who feel at home in landscapes dominated by forests; lowest $\mathrm{C}(\mathrm{p})$ level: Individual experiences in nature areas without facilities for outdoor recreation.

(2). People who feel at home in landscapes dominated by coasts; lowest $\mathrm{C}(\mathrm{p})$ level: Individual experiences in nature at the sea beach or archipelago; and jogging and cycling at the sea beach or archipelago.

(3). People who feel at home in landscapes dominated by rolling hills and lakes; lowest $\mathrm{C}(\mathrm{p})$ level: Winter sport close to or on open water covered by ice; and individual experiences in nature close to or on open water.

(4). People who feel at home in landscapes dominated by agricultural plains; lowest $\mathrm{C}(\mathrm{p})$ level: Winter sport close to or on open water covered by ice; and individual experiences in natural areas without facilities for outdoor recreation.

For people who have moved from their childhood region:

(1). People who feel at home in landscapes dominated by forests; lowest $\mathrm{C}(\mathrm{p})$ level: Taking walks in nature areas without facilities for outdoor recreation.

(2). People who feel at home in landscapes dominated coasts; lowest $\mathrm{C}(\mathrm{p})$ level: Taking walks in nature at the sea beach or archipelago. 
(3). People who feel at home in landscapes dominated rolling hills and lakes; lowest $\mathrm{C}(\mathrm{p})$ level: Winter sport close to or on open water covered by ice.

(4). People who feel at home in landscapes dominated agricultural plains; lowest $\mathrm{C}(\mathrm{p})$ level: Taking walks in nature areas without facilities for outdoor recreation; and gardening and culture close to natural areas without facilities for outdoor recreation.

\section{Discussion}

Attachment behaviour concerns adjusting more or less to changes in the environment; i.e., if these changes do not differ too greatly from the environment where the system was developed during childhood (Bowlby, 1980). Behaviour is partly determined by learned habits originating from previous life experiences and by stimuli in the immediate environment. When these perspectives are integrated, an interpretation of what is happening is closely connected to an attachment process (Bowlby, 1980). We maintain that our results can be interpreted as pointing to similarities with what happens in a related process. That is feelings of security and trust, or the lack thereof the strong emotional bond that develops between the child and its primary caregiver as one process and the attachment to a certain type of landscape, including activities relating to that type of landscape as a parallel example. In Attachment Theory, humans' first years of life seem to involve a sensitive period during which they shape their first attachments to caregivers (Bowlby, 1980). The bond in the original Attachment Theory enhances social and personality adjustments later in life (Masten \& Coatsworth, 1998; Schore, 1996). With an interpretation of our results regarding which types of landscapes people choose as places of recreation and for recreation activities, the environmental attachment process also seems to involve a sensitive or fragile period during growth, influencing how the individual refers to these factors later in life. While the original Attachment Theory involves how the individual is "coloured" throughout life when it comes to personality traits and bonding with other people (relationships), our "environmental attachment process" also seems to have a strong influence on the individual as an adult.

A point of departure for this project was to study whether people become more attached to certain landscape types and moreover to activities associated with these types of landscapes. This study shows that people who feel at home in a particular type of landscape do visit recreation areas associated with that type of landscape more often (Table 1). This pattern can possibly be due to the fact that our respondents became attached to these types of nature during their childhood and adolescence. Moreover, our results clearly show that people who feel at home in particular types of landscapes perform certain outdoor activities more often, which may be because they, since childhood, have a deeper understanding that these activities can be accomplished best there (Table 3). The results are thus interpreted such that people tend to devote themselves to activities associated with where they feel they belong. Specific analyses were conducted concerning people who have moved from their childhood region (Table 1,3). The pattern showed high consistency, which leads us to presume that habits are established early. Our findings support earlier studies by e.g., Kyle et al. (2003) and Gross and Brown (2008), who maintained that place attachment is an important factor to consider in explaining recreation behaviour. Moreover, these findings seem to support attachment phenomena connected to the old concept of Heimat (Applegate, 1990; Blickle, 2004).

Consequently: whether or not our respondents have moved, feeling at home in a particular type of landscape has importance for their choice of setting as well as recreational activity. Hypothetically, some activities, such as "social activities" and "jogging" should not be specifically linked to any of the four landscape types. Nevertheless, in Table 3 we find some strong associations between how often people have performed these types of activities, and in which type of landscape they felt at home. For instance, people who feel at home in coastal areas choose bathing and sunbathing as well as jogging (Table 3), preferably at the sea beach or archipelago (Table 1; Chapter 4.6). We interpret this as a kind of attachment process (Kyle et. al., 2003; Masten \& Coatsworth, 1998).

Earlier studies suggest that recreation in natural environments restores people from stress (e.g. Annerstedt et al., 2010; Hartig, Evans, Jamner, Davis, \& Gärling, 2003) and that the most restorative experiences are connected to nature-related activities (e.g. Sugiyama \& Ward Thompson, 2007). Our aim was to investigate whether people are more restored after performing outdoor activities in landscapes where they feel at home. From the questionnaire, we could distinguish a factor LS (level of stress) consisting of the complaints irritation, stress and fatigue; this was in line with findings from, e.g. Annerstedt et al. (2010). In addition, we found that lower levels of stress were most related to the length of the respondents' stay at recreation areas - not primarily the frequency of their visits (Table 5). This result supports earlier studies (Annerstedt et al., 2010; Cason \& Gillis, 1994; Grahn $\&$ Stigsdotter, 2003). This may lead to the conclusion that stress is related to time shortage. This should also 
have implications on people's perception of nature. 'Mental restoration' covers processes through which people recover adaptive resources that they have diminished in efforts to meet the demands of everyday life (Nilsson et al., 2011). Because a person depletes resources in meeting everyday demands, a potential or need for restoration arises regularly. As new demands come along, the person must restore the depleted resources or risk not being able to meet these new demands. Over time, inadequate restoration can translate into problems, often stress-related (Nilsson et al., 2011). Kaplan and Kaplan (1989) talk about people's need to regularly be able to find places where they feel they can "be away", not least mentally. Places where they feel permissiveness and can be fascinated by the ambient richness and details - without being completely engulfed by what is happening: It is important that the environment at the same time provides opportunities for reflection. Nature includes all that, but it requires time for a person to achieve such permission.

Activities most associated with lower stress levels seem to involve people more directly in nature processes. An ANOVA Type III analysis, in which each of the activity types was placed last in the model (Table 6), showed that individual experiences in nature had a strong association with lower stress levels for people who feel at home in a specific type of landscape. For the subgroups that have moved from their childhood region, wilderness activities have this effect. The most striking result was that this pattern was principally similar for all people, regardless of which landscape type they felt at home in. The results show that when people experience stress, they participate in activities that place them in more direct contact with nature. However, for people who have moved from their childhood area, the activities seem to involve more planning and preparatory work, such as wilderness activities. These people probably do not have easy access to preferred places in their neighbourhood, or to prerequisites like boats. So, an explanation could be either that they need to make an extra effort to perform wilderness activities, or that they walk in their neighbourhood instead of having individual experiences at their favourite places from childhood. In this study, people who experience stress seem to avoid performing outdoor activities where they might run the risk of meeting other people (such as social activities). Ottosson and Grahn (2008) found that experiencing nature has a more powerful influence on the rehabilitation potential of people greatly affected by a crisis, while social activities had more influence on people who were less affected by a crisis. In addition, Tenngart Ivarsson and Grahn (2010) found that people in a rehabilitation garden - at the beginning of their rehabilitation - most of all wanted to escape to and stay in enclosed areas that resemble nature: people, and/or signs of human activity, might increase the demands on how to behave and thus also increase the risk of higher levels of stress.

When the activity types were combined with recreation areas and "level of stress" was included in our analyses, the results showed that people experiencing low levels of stress choose individual experiences (or jog or participate in winter sport) at recreation areas relating to the landscape type they feel at home in. Roger Ulrich (1999) argued that the sensory impact of the environment may signal danger or safety, and that this is most important when people experience stress. In his Affective Aesthetic Theory, he claims that activities in nature with certain qualities restore our stress levels to normal. We maintain that people find these qualities, which induce feelings of safety, much more easily in nature areas they are attached to.

The strength of this study is the relatively large volume of empirical material. It is also advantageous that the questions in the survey concerned ordinary activities in ordinary settings, with no experimental character, making the results more appropriate for generalizing. However, this is a cross-sectional study, and thus cause and effect relationships are not certain. What the material seem to indicate, is that people who live in areas they find correspond with a "feeling at home" seem to have more easy to find places to carry out recreational activities they want to carry out, and this affects their levels of stress. However, we have no possibilities to examine whether these people have immediate access or not to places to carry out recreational activities they want to carry out. In addition, we have no opportunity to examine whether certain professional groups in their professions, pursuing specific outdoor activities more often. And of course, some activities (e.g. "winter sports", "sun and bathing") can be performed only seasonally, and this could bias the comparison with other activities that can be done all year around. More studies are therefore needed, including qualitative and, if possible, longitudinal studies. An experimental design, including measures of the immediate stress-reducing effect of activities or settings, would also be of interest in future research.

\section{Conclusion}

Our results indicate that activities involving more direct contact with familiar nature areas are associated with lower stress levels. A person suffering from stress cannot manage too many unfamiliar impressions that are difficult to sort out and respond to; they react to these impressions as they would to a threat (Grahn et al., 2010). Instead, the simple and the familiar can be interpreted as something secure; something they can trust and rely on. The need to ease off in stressful situations, in familiar natural environments, including familiar activities and at a 
pace our "origin" indicates, can involve a beneficial but presumably unconscious strategy. The simple, non-pretentious and most of all more familiar is possibly more efficient for stress reduction, with people experiencing less energy and stamina. Our results suggest not only that nature-related activities seem to reduce levels of stress; people having lower levels of stress also choose to perform these activities at places where they feel more at home. This knowledge is important when discussing how to design and plan outdoor areas, especially in our multicultural urban society. The phenomenon of feeling at home in a natural environment should be seen as a more important factor than it has in the past.

\section{References}

Adevi, A.A., \& Grahn, P. (in press). Preferences for landscapes: A matter of cultural determinants or innate reflexes that point to our evolutionary background? Landscape Research, http://dx.doi.org/10.1080/01426397.2011.576884

Annerstedt, M., Norman J., Boman M., Mattsson L., Grahn P., \& Währborg, P. (2010). Finding stress relief in a forest. Ecological Bulletins, 53, 33-42.

Applegate, C. (1990). A nation of provincials. The German idea of Heimat. Berkeley, CA: University of California Press.

Bell, S. (1999). Landscape: Pattern, perception and process. New York, NY: E. \& F. N. Spon.

Blickle, P. (2004). Heimat. A critical theory of the German idea of homeland. Rochester, NY: Camden House.

Bodin, M., \& Hartig, T. (2003). Does the outdoor environment matter for psychological restoration gained through running? Psychology of Sport Exercise, 4, 141-153. http://dx.doi.org/10.1016/S1469-0292(01)00038-3

Boverket. (2006). Vad händer med kusten? [What is happening with the coast?] Retrieved from http://www.boverket.se/Global/Webbokhandel/Dokument/2006/vad_hander_med_kusten.pdf

Bowlby, J. (1969). Attachment. New York, NY: Basic Books.

Bowlby, J. (1980). Loss: Sadness \& depression. London, England: Hogarth Press.

Cason, D., \& Gillis, H.L. (1994). A meta-analysis of outdoor adventure programming with adolescents. Journal of Experiential Education, 17, 40-47.

Cimprich, B. (1993). Development of an intervention to restore attention in cancer patients. Cancer Nursing, 16, 83-92. http://dx.doi.org/10.1097/00002820-199304000-00001

Csikszentmihalyi, M. (1975). Beyond boredom and anxiety. San Francisco, CA: Jossey-Bass.

De Grazia, S. (1962). Of time, work and leisure. New York, NY: Twentieth Century Fund.

Driver, B.L., Brown, P.J., Stankey, G.H., \& Gregoire, T.G. (1987). The ROS planning system: Evolution, basic concepts, and research needed. Leisure Sciences, 9, 201-212. http://dx.doi.org/10.1080/01490408709512160

Gibson, J.J. (1979). The ecological approach to visual perception. Boston, MA: Houghton Mifflin.

Grahn, P. (1991). Using tourism to protect existing culture: A project in Swedish Lapland. Leisure Studies, 10, 33-47. http://dx.doi.org/10.1080/02614369100390041

Grahn, P., \& Stigsdotter U. (2003). Landscape planning and stress. Urban Forestry \& Urban Greening, 2, 1 - 18. http://dx.doi.org/10.1078/1618-8667-000198

Grahn, P., \& Stigsdotter, U.K. (2010). The relation between perceived sensory dimensions of urban green space and stress restoration. Landscape and Urban Planning, 94, 264-275. http://dx.doi.org/10.1016/j.landurbplan.2009.10.012

Grahn, P., Tenngart Ivarsson, C., Stigsdotter U.K., \& Bengtsson, I.L. (2010). Using affordances as a health-promoting tool in a therapeutic garden. In C. Ward Thompson, S. Bell, \& P. Aspinall (Eds.), Innovative approaches to researching landscape and health (pp. 116-154). London, England: Routledge.

Gross, M.J., \& Brown, G. (2008). An empirical structural model of tourists and places: Progressing involvement and place attachment into tourism. Tourism Management, 29, 1141-1151. http://dx.doi.org/10.1016/j.tourman.2008.02.009

Hartig, T., Evans, G.W., Jamner, L., Davis, D., \& Gärling, T. (2003). Tracking restoration in natural and urban $\begin{array}{lllll}\text { field settings. Journal of Environmental Psychology, } & 23, & 109-123 .\end{array}$ http://dx.doi.org/10.1016/S0272-4944(02)00109-3 
Heft, H. (2010). Affordances and the perception of landscape. In C. Ward Thompson, S. Bell, \& P. Aspinall (Eds.), Innovative approaches to researching landscape and health (pp. 9-32). London, England: Routledge.

Hjort, B. (1983). Var hör människan hemma? [Where do human beings belong and feel at home?] (Doctoral dissertation). Stockholm, Sweden: Department of architecture, the Royal Institute of Technology.

Iso-Ahola, S.E. (1980). The social psychology of leisure and recreation. Dubuque, IA: Wm. C. Brown Company Publishers.

Kaplan, R., \& Kaplan, S. (1989). The experience of nature: A psychological perspective. New York, NY: Cambridge University Press.

Kaups, M. (1995). Cultural landscape: Log structures as symbols of ethnic identity. Material Culture, 27(2), $1-19$.

Kyle, G., Graefe, A., Manning, R., \& Bacon, J. (2003). An examination of the relationship between leisure activity involvement and place attachment among hikers along the Appalachian Trail. The Journal of Leisure Research, 35, 249-273.

Landscape Convention. Council of Europe Treaty Series no. 176. (2000). Florence, Italy: Council of Europe.

Loukinen, M.M. (1996). Cultural tracks: Finnish Americans in Michigan's upper peninsula. In M. Marsden, \& R. Magnaghi (Eds.), A sense of place, Michigan's upper peninsula: Essays in honor of the career of William Vandament (pp. 15-34). Marquette, MI: Northern Michigan University Press.

Low, SM., \& Altman I. (1992). Place attachment: A conceptual inquiry. In I. Altman, \& S.M. Low (Eds.), Place attachment (pp. 1-12). New York, NY: Plenum.

Manly, B.F.J. (1994). Multivariate statistical methods: A primer (2nd ed). London, England: Chapman \& Hall.

Manning, R.E. (1999). Studies in outdoor recreation. Corvallis, OR: Oregon State University Press.

Masten, A. S., \& Coatsworth, J. D. (1998). The development of competence in favorable and unfavorable environments: Lessons from research on successful children. American Psychologist, 53, 205-220. http://dx.doi.org/10.1037/0003-066X.53.2.205

Morgan, M., \& Messenger, B. (2009). Using activity and place-based typology to explain visitor motivations. Journal of Forestry, 107, 44-49.

Nilsson, K., Sangster, M., Gallis, C., Hartig, T., de Vries, S., Seeland, K., \& Schipperijn, J. (Eds.). (2011). Forests, trees, and human health. Berlin, Germany: Springer.

Noble, A.G. (Ed.). (1992). To build in a new land: Ethnic landscapes in North America. Baltimore, MD: Johns Hopkins University Press.

Nordh, H., Grahn, P., \& Währborg, P. (2009). Meaningful activities in the forest: A way back from exhaustion and long-term sick leave. Urban Forestry \& Urban Greening, 8, 207-219. http://dx.doi.org/10.1016/j.ufug.2009.02.005

Nyström, C., \& Nyström, O. (1995). Stress and crisis inventory - SCI-93: A process-oriented personality exploration starting from a crisis-theoretical frame of reference. Manual. Partille, Sweden: Nyström och Nyström Förlag.

Nyström, C., \& Nyström, O. (1996). Skattad stress verifierbar: Autonom dysfunktion [Estimated stress verified: Autonomic dysfunction]. Läkartidningen, 93, 28-29.

Ottosson, J., \& Grahn, P. (2008). The role of natural settings in crisis rehabilitation. Landscape Research, 33, 51-70. http://dx.doi.org/10.1080/01426390701773813

Paasi, A. (1997). Geographical perspectives on Finnish national identity. GeoJournal, 43(1), 41-50. http://dx.doi.org/10.1023/A:1006885503314

Pierskalla, C.D., Lee, M.E., Stein, T.V., Anderson, D.H., \& Nickerson, R. (2004). Understanding relationships among recreation opportunities: A meta-analysis of nine studies. Leisure Sciences, 26, 163-180. http://dx.doi.org/10.1080/01490400490432082

SAS Statistics. (2009). SAS 9.2 documentation; SAS Institute, Inc. release 9.2. Cary, NC: SAS, Retrieved from http://support.sas.com/documentation/cdl_main/ 
Schore, A. N. (1996). The experience-dependent maturation of a regulatory system in the orbital refrontal cortex and the origin of developmental psychopathology. Development and Psychopathology, 8, 59-87. http://dx.doi.org/10.1017/S0954579400006970

Statistical yearbook of Sweden 2009: Official statistics of Sweden. (2009). Stockholm: Statistics Sweden.

Stigsdotter, U.K., \& Grahn, P. (in press). Stressed individual's preferences for activities and environmental characteristics in urban green spaces Urban Forestry \& Urban Greening.

Sugiyama, T., \& Ward Thompson, C. (2007). Older people's health, outdoor activity and supportiveness of $\begin{array}{lllll}\text { neighbourhood. Landscape and Urban } & \text { Planning, } & \text { 83, } & \text { 168-175. }\end{array}$ http://dx.doi.org/10.1016/j.landurbplan.2007.04.002

Sveriges nationalatlas: Sveriges geografi [National atlas of Sweden: The geography of Sweden]. (1996). S. Helmfrid (Ed.). Stockholm, Sweden: Bra Böcker.

Swedish socio-economic classification reports on statistical co-ordination. (1995). Stockholm, Sweden: Statistics Sweden.

Tenngart Ivarsson, C., \& Grahn, P. (2010). Patients' experiences and use of a therapeutic garden: From a designer's perspective. Schweizerische Zeitschrift für Forstwesen, 161, 104-113. http://dx.doi.org/10.3188/szf.2010.0104

Ulrich, R.S. (1999). Effects of gardens on health outcomes: Theory and research. In C. Cooper Marcus, \& M. Barnes (Eds.), Healing gardens: Therapeutic benefits and design recommendations (pp. 27-86). New York, NY: John Wiley.

Velarde, M.D., Fry, G., \& Tveit, M. (2007). Health effects of viewing landscapes: Landscape types in environmental psychology. Urban Forestry \& Urban Greening, 6, 199-212. http://dx.doi.org/10.1016/j.ufug.2007.07.001

Ward, C., \& Styles, I. (2007). Evidence for the ecological self: English-speaking migrants' residual links to their homeland. International Journal of Applied Psychoanalytic Studies, 4, 319-332. http://dx.doi.org/10.1002/aps.101

Table 1. Associations between visits to natural recreation areas and feeling at home in a certain type of landscape

\begin{tabular}{|c|c|c|c|c|c|c|c|c|}
\hline & \multicolumn{2}{|c|}{ Forest } & \multicolumn{2}{|c|}{ Coast } & \multicolumn{2}{|c|}{$\begin{array}{l}\text { Rolling hills and } \\
\text { lakes }\end{array}$} & \multicolumn{2}{|c|}{$\begin{array}{l}\text { Agricultural } \\
\text { plains }\end{array}$} \\
\hline & All & Moved & All & Moved & All & Moved & All & Moved \\
\hline $\begin{array}{l}\text { Natural area with } \\
\text { facilities for outdoor } \\
\text { activities, such as } \\
\text { parking places, } \\
\text { marked trails, and } \\
\text { /or barbecue }\end{array}$ & $\begin{array}{c}1.78 \\
\mathrm{~ns}\end{array}$ & $\begin{array}{c}1.87 \\
\mathrm{~ns}\end{array}$ & $\begin{array}{c}6.08 \\
\mathrm{p}<0.05\end{array}$ & $\begin{array}{c}5.56 \\
\mathrm{p}<0.05\end{array}$ & $\begin{array}{c}2.99 \\
\text { ns }\end{array}$ & $\begin{array}{c}4.47 \\
p<0.05\end{array}$ & $\begin{array}{c}0.18 \\
\mathrm{~ns}\end{array}$ & $\begin{array}{c}0.01 \\
\mathrm{~ns}\end{array}$ \\
\hline $\begin{array}{l}\text { Natural area without } \\
\text { facilities for outdoor } \\
\text { recreation }\end{array}$ & $\begin{array}{c}24.59 \\
\mathrm{p}<0.0001\end{array}$ & $\begin{array}{c}12.59 \\
\mathrm{p}<0.0001\end{array}$ & $\begin{array}{c}8.27 \\
\mathrm{p}<0.01 \\
\mathrm{Neg}\end{array}$ & $\begin{array}{c}9.32 \\
\mathrm{p}<0.01 \\
\mathrm{Neg} \\
\end{array}$ & $\begin{array}{c}0.70 \\
\mathrm{~ns}\end{array}$ & $\begin{array}{c}0.19 \\
\text { ns }\end{array}$ & $\begin{array}{c}4.00 \\
p<0.05\end{array}$ & $\begin{array}{c}1.91 \\
\mathrm{~ns}\end{array}$ \\
\hline $\begin{array}{l}\text { Beach/bathing place } \\
\text { at the lake or sea }\end{array}$ & $\begin{array}{c}2.56 \\
\text { ns } \\
\text { Neg }\end{array}$ & $\begin{array}{c}2.28 \\
\text { ns } \\
\text { Neg }\end{array}$ & $\begin{array}{c}8.23 \\
\mathrm{p}<0.01\end{array}$ & $\begin{array}{c}2.47 \\
\mathrm{~ns}\end{array}$ & $\begin{array}{c}1.72 \\
\mathrm{~ns}\end{array}$ & $\begin{array}{c}0.16 \\
\text { ns }\end{array}$ & $\begin{array}{c}1.69 \\
\text { ns } \\
\text { Neg }\end{array}$ & $\begin{array}{c}4.36 \\
\mathrm{p}<0.05 \\
\mathrm{Neg} \\
\end{array}$ \\
\hline $\begin{array}{c}\text { Open water, } \\
\text { accessible by boat or } \\
\text { canoe }\end{array}$ & $\begin{array}{c}0.60 \\
\text { ns } \\
\text { Neg } \\
\end{array}$ & $\begin{array}{c}0.28 \\
\text { ns } \\
\text { Neg } \\
\end{array}$ & $\begin{array}{c}16.75 \\
p<0.001\end{array}$ & $\begin{array}{c}5.56 \\
\mathrm{p}<0.05\end{array}$ & $\begin{array}{c}17.92 \\
p<0.0001\end{array}$ & $\begin{array}{c}10.45 \\
\mathrm{p}<0.001\end{array}$ & $\begin{array}{c}0.96 \\
\text { ns } \\
\text { Neg }\end{array}$ & $\begin{array}{c}4.55 \\
\mathrm{p}<0.05 \\
\mathrm{Neg} \\
\end{array}$ \\
\hline $\begin{array}{l}\text { Sea beach or } \\
\text { archipelago }\end{array}$ & $\begin{array}{c}29.49 \\
\mathrm{p}<0.0001 \\
\mathrm{Neg} \\
\end{array}$ & $\begin{array}{c}18.46 \\
\mathrm{p}<0.0001 \\
\mathrm{Neg} \\
\end{array}$ & $\begin{array}{c}103.27 \\
\mathrm{p}<0.0001\end{array}$ & $\begin{array}{c}49.42 \\
p<0.0001\end{array}$ & $\begin{array}{c}7.53 \\
\mathrm{p}<0.01 \\
\mathrm{Neg}\end{array}$ & $\begin{array}{c}6.98 \\
\mathrm{p}<0.01 \\
\mathrm{Neg}\end{array}$ & $\begin{array}{c}0.94 \\
\text { ns } \\
\text { Neg }\end{array}$ & $\begin{array}{c}1.89 \\
\text { ns } \\
\text { Neg }\end{array}$ \\
\hline MANOVA & $\begin{array}{c}15.05 \\
p<0.0001\end{array}$ & $\begin{array}{c}9.06 \\
\mathrm{p}<0.0001\end{array}$ & $\begin{array}{c}25.49 \\
p<0.0001\end{array}$ & $\begin{array}{c}13.43 \\
\mathrm{p}<0.0001\end{array}$ & $\begin{array}{c}7.97 \\
p<0.001\end{array}$ & $\begin{array}{c}4.43 \\
p<0.01\end{array}$ & $\begin{array}{c}1.60 \\
\mathrm{~ns}\end{array}$ & $\begin{array}{c}2.13 \\
\mathrm{~ns}\end{array}$ \\
\hline
\end{tabular}

MANOVA, Type III, Wilks' Lambda, and ANOVA, Type III. Model: Visiting different kinds of natural recreation areas, number of times (outcome) $=$ Feeling at home in a certain type of landscape, Sex, Socio-economic Standard (SES) (all independent, Sex and SES not shown). F-values and p-values. Number of observations =1,325 (all) and 823 (moved). 
Table 2. Associations between different outdoor activities

\begin{tabular}{|c|c|c|c|}
\hline Cluster & Variables & $\begin{array}{c}\text { Proportion } \\
\text { explained }\end{array}$ & Interpretation \\
\hline 1 & $\begin{array}{c}\text { Hiking and spending the night in a tent; Fishing; } \\
\text { Picking berries; Picking mushrooms }\end{array}$ & 62 & Wilderness activities \\
\hline 2 & $\begin{array}{c}\text { Outings with family and friends; Resting and relaxing; } \\
\text { Going out and having a look at people }\end{array}$ & 47 & Social activities \\
\hline 3 & Sunbathing; Bathing in the lake or sea & 56 & Sun and bathing \\
\hline 4 & Gardening; Enjoying cultural environments & 80 & Gardening and culture \\
\hline 5 & Cross-country skiing; Downhill skiing; Skating & 61 & Winter sport \\
\hline 6 & Boating; Looking at the view; Picnic/barbecue & 63 & Boating and view \\
\hline 7 & $\begin{array}{c}\text { Going out to be by myself; Outing with the dog; } \\
\text { Studying birds and plants; Hunting; Taking photos }\end{array}$ & 61 & Individual experiences in \\
nature
\end{tabular}

Varclus disjoint oblique principal component cluster analysis, with orthoblique initialization. Proportion of variation explained by clusters 0.6008 . No clusters met the criterion for splitting after ten clusters. Number of observations $=1,325$.

Table 3. Associations between performing outdoor activity types and feeling at home in a certain type of landscape

\begin{tabular}{|c|c|c|c|c|c|c|c|c|}
\hline \multirow[t]{2}{*}{$\begin{array}{l}\text { Activity type, } \\
\text { recoded values }\end{array}$} & \multicolumn{2}{|c|}{ Forest } & \multicolumn{2}{|c|}{ Coast } & \multicolumn{2}{|c|}{$\begin{array}{c}\text { Rolling hills and } \\
\text { lakes }\end{array}$} & \multicolumn{2}{|c|}{ Agricultural plains } \\
\hline & All & Moved & All & Moved & All & Moved & All & Moved \\
\hline $\begin{array}{c}\text { Wilderness } \\
\text { activities }\end{array}$ & $\begin{array}{c}8.71 \\
p<0.01\end{array}$ & $\begin{array}{c}12.08 \\
p<0.001\end{array}$ & $\begin{array}{c}7.84 \mathrm{p}<0.01 \\
\text { Neg }\end{array}$ & $\begin{array}{c}3.79 \mathrm{p}<0.05 \\
\text { Neg }\end{array}$ & $\begin{array}{c}0.02 \\
\text { ns } \\
\text { Neg }\end{array}$ & $\begin{array}{c}0.03 \\
\text { ns } \\
\text { Neg } \\
\end{array}$ & $\begin{array}{c}0.37 \\
\mathrm{~ns}\end{array}$ & $\begin{array}{c}1.97 \\
p<0.05\end{array}$ \\
\hline $\begin{array}{c}\text { Social } \\
\text { activities }\end{array}$ & $\begin{array}{c}0.13 \\
\text { ns } \\
\text { Neg }\end{array}$ & $\begin{array}{c}9.81 \\
\mathrm{p}<0.001 \\
\text { Neg }\end{array}$ & $\begin{array}{c}0.42 \\
\mathrm{~ns}\end{array}$ & $\begin{array}{c}0.19 \\
\text { ns }\end{array}$ & $\begin{array}{c}0.40 \\
\text { ns } \\
\text { Neg }\end{array}$ & $\begin{array}{c}0.84 \\
\text { ns } \\
\text { Neg }\end{array}$ & $\begin{array}{c}2.68 \\
p<0.05\end{array}$ & $\begin{array}{c}0.49 \\
\text { ns }\end{array}$ \\
\hline $\begin{array}{l}\text { Sun and } \\
\text { bathing }\end{array}$ & $\begin{array}{c}0.01 \\
\text { ns } \\
\text { Neg }\end{array}$ & $\begin{array}{c}0.24 \\
\text { ns } \\
\text { Neg }\end{array}$ & $\begin{array}{c}4.09 \\
p<0.01\end{array}$ & $\begin{array}{c}3.94 \\
p<0.01\end{array}$ & $\begin{array}{c}0.43 \\
\mathrm{~ns}\end{array}$ & $\begin{array}{c}0.04 \\
\text { ns }\end{array}$ & $\begin{array}{c}2.02 \\
\mathrm{p}<0.05 \\
\text { Neg }\end{array}$ & $\begin{array}{c}2.28 \\
\mathrm{p}<0.05 \\
\text { Neg }\end{array}$ \\
\hline $\begin{array}{l}\text { Gardening and } \\
\text { culture }\end{array}$ & $\begin{array}{c}0.14 \\
\mathrm{~ns}\end{array}$ & $\begin{array}{c}0.68 \\
\mathrm{~ns}\end{array}$ & $\begin{array}{c}0.22 \\
\mathrm{~ns}\end{array}$ & $\begin{array}{c}0.61 \\
\mathrm{~ns}\end{array}$ & $\begin{array}{c}0.66 \\
\mathrm{~ns}\end{array}$ & $\begin{array}{c}0.84 \\
\mathrm{~ns}\end{array}$ & $\begin{array}{c}11.76 \\
\mathrm{p}<0.001\end{array}$ & $\begin{array}{c}10.61 \\
\mathrm{p}<0.001\end{array}$ \\
\hline Winter sport & $\begin{array}{c}0.41 \\
\mathrm{~ns}\end{array}$ & $\begin{array}{c}0.12 \\
\mathrm{~ns}\end{array}$ & $\begin{array}{c}0.20 \\
\mathrm{~ns}\end{array}$ & $\begin{array}{c}0.08 \\
\text { ns }\end{array}$ & $\begin{array}{c}1.91 \\
p<0.05\end{array}$ & $\begin{array}{c}5.74 \\
p<0.01\end{array}$ & $\begin{array}{c}2.46 \\
\mathrm{p}<0.05 \\
\mathrm{Neg}\end{array}$ & $\begin{array}{c}2.18 \\
\mathrm{p}<0.05 \\
\mathrm{Neg}\end{array}$ \\
\hline $\begin{array}{l}\text { Boating and } \\
\text { view }\end{array}$ & $\begin{array}{c}0.02 \\
\text { ns } \\
\text { Neg }\end{array}$ & $\begin{array}{c}7.25 \\
\mathrm{p}<0.01 \\
\text { Neg }\end{array}$ & $7.12 \mathrm{p}<0.01$ & $3.76 \mathrm{p}<0.05$ & $\begin{array}{c}10.82 \\
p<0.001\end{array}$ & $\begin{array}{c}1.04 \\
\mathrm{~ns}\end{array}$ & $\begin{array}{c}1.12 \\
\mathrm{~ns}\end{array}$ & $\begin{array}{c}1.01 \\
\text { ns }\end{array}$ \\
\hline $\begin{array}{c}\text { Individual } \\
\text { experiences in } \\
\text { nature }\end{array}$ & $\begin{array}{c}0.27 \\
\mathrm{~ns}\end{array}$ & $\begin{array}{c}1.34 \\
\mathrm{~ns}\end{array}$ & $\begin{array}{c}2.48 \\
\mathrm{p}<0.05 \\
\text { Neg }\end{array}$ & $\begin{array}{c}2.33 \\
\mathrm{p}<0.05 \\
\text { Neg }\end{array}$ & $\begin{array}{c}1.04 \\
\text { ns } \\
\text { Neg }\end{array}$ & $\begin{array}{c}1.10 \\
\mathrm{~ns} \\
\mathrm{Neg}\end{array}$ & $\begin{array}{c}2.82 \\
\mathrm{p}<0.05\end{array}$ & $\begin{array}{c}1.07 \\
\mathrm{~ns}\end{array}$ \\
\hline $\begin{array}{l}\text { Horseback } \\
\text { riding and golf }\end{array}$ & $\begin{array}{c}3.39 \\
p<0.05\end{array}$ & $\begin{array}{c}2.06 \\
p<0.05\end{array}$ & $\begin{array}{c}0.13 \\
\text { ns } \\
\text { Neg } \\
\end{array}$ & $\begin{array}{c}0.66 \\
\text { ns } \\
\text { Neg }\end{array}$ & $\begin{array}{c}0.88 \\
\text { ns }\end{array}$ & $\begin{array}{c}0.01 \\
\mathrm{~ns}\end{array}$ & $\begin{array}{c}2.44 \\
\mathrm{p}<0.05\end{array}$ & $\begin{array}{c}2.20 \\
\mathrm{p}<0.05\end{array}$ \\
\hline $\begin{array}{c}\text { Taking walks } \\
\text { in nature }\end{array}$ & $\begin{array}{c}13.05 \\
p<0.001\end{array}$ & $\begin{array}{c}4.70 \\
p<0.01\end{array}$ & $\begin{array}{c}2.46 \\
\mathrm{p}<0.05\end{array}$ & $\begin{array}{c}0.80 \\
\mathrm{~ns}\end{array}$ & $\begin{array}{c}25.76 \\
p<0.0001 \\
\end{array}$ & $\begin{array}{c}4.77 \\
p<0.01\end{array}$ & $\begin{array}{c}3.04 \\
p<0.05\end{array}$ & $\begin{array}{c}0.18 \\
\mathrm{~ns}\end{array}$ \\
\hline $\begin{array}{l}\text { Jogging and } \\
\text { cycling }\end{array}$ & $\begin{array}{c}1.82 \\
\text { ns } \\
\text { Neg }\end{array}$ & $\begin{array}{c}0.01 \\
\text { ns } \\
\text { Neg }\end{array}$ & $6.67 p<0.01$ & $4.90 \mathrm{p}<0.01$ & $\begin{array}{c}0.01 \\
\mathrm{~ns}\end{array}$ & $\begin{array}{c}0.13 \\
\text { ns } \\
\text { Neg }\end{array}$ & $\begin{array}{c}0.01 \\
\text { ns } \\
\text { Neg }\end{array}$ & $\begin{array}{c}1.18 \\
\text { ns } \\
\text { Neg }\end{array}$ \\
\hline MANOVA & $\begin{array}{c}5.22 \\
\mathrm{p}<0.01\end{array}$ & $\begin{array}{c}8.91 \\
\mathrm{p}<0.001\end{array}$ & $\begin{array}{c}6.53 \\
p<0.01\end{array}$ & $\begin{array}{c}3.20 \\
p<0.05\end{array}$ & $\begin{array}{c}7.91 \\
p=0.001\end{array}$ & $\begin{array}{c}3.14 \\
p<0.05\end{array}$ & $\begin{array}{c}5.19 \\
p<0.01\end{array}$ & $\begin{array}{c}4.61 \\
p<0.01\end{array}$ \\
\hline
\end{tabular}

MANOVA, Type III, Wilks' Lambda, and ANOVA, Type III. Model: Activity type 1-10 (outcome) = Landscape type, Sex, Socio-economic Standard (SES) (all independent, Sex and SES not shown). F-values and p-values. Number of observations = 1,325 (all) and 823 (moved). 
Table 4. Factor Analysis

\begin{tabular}{|c|c|c|}
\hline & Factor 1 & Factor 2 \\
\hline Felt irritated & 0.85 & \\
\hline Felt stressed & 0.84 & \\
\hline Felt fatigued & 0.67 & \\
\hline Had strong headache & 0.43 & \\
\hline Had cold (viral infection) & 0.35 & \\
\hline Had pain in the nape of the neck & & 0.76 \\
\hline Had pain in back & & 0.75 \\
\hline
\end{tabular}

Promax rotation, of stress-related complaints. Number of observations $=1,325$.

Table 5. Associations between people's levels of stress and visits to natural recreation areas

\begin{tabular}{|c|c|c|}
\hline & F-value & P-value \\
\hline Number of visits to natural areas & 2.53 & $\mathrm{~ns}$ \\
\hline Time spent in natural areas & 9.95 & $\mathrm{p}<0.01$ \\
\hline SES & 0.59 & $\mathrm{~ns}$ \\
\hline
\end{tabular}

ANOVA, Type III. Model: LS (outcome) = Number of visits to natural areas, Time spent in natural areas, Socio-economic Standard (SES) (all independent). Number of observations $=1,325$.

Table 6. Associations between how often people perform activity types and lower levels of stress, distributed by landscape types people feel at home in

\begin{tabular}{|c|c|c|c|c|c|c|c|c|}
\hline \multirow[t]{2}{*}{$\begin{array}{c}\text { Activity type, recoded } \\
\text { values }\end{array}$} & \multicolumn{2}{|c|}{ Forest } & \multicolumn{2}{|c|}{ Coast } & \multicolumn{2}{|c|}{$\begin{array}{l}\text { Rolling hills and } \\
\text { lakes }\end{array}$} & \multicolumn{2}{|c|}{ Agricultural plains } \\
\hline & All & Moved & All & Moved & All & Moved & All & Moved \\
\hline Wilderness activities & $0.77 \mathrm{~ns}$ & $\begin{array}{c}7.46 \\
p<0.01\end{array}$ & $0.47 \mathrm{~ns}$ & $\begin{array}{c}4.65 \\
p<0.05\end{array}$ & $0.09 \mathrm{~ns}$ & $\begin{array}{c}4.67 \\
p<0.05\end{array}$ & $\begin{array}{c}0.05 \\
\text { ns }\end{array}$ & $1.45 \mathrm{~ns}$ \\
\hline Social activities & $0.66 \mathrm{~ns}$ & $1.28 \mathrm{~ns}$ & $0.88 \mathrm{~ns}$ & $0.98 \mathrm{~ns}$ & $\begin{array}{c}\text { Neg } \\
0.61 \mathrm{~ns}\end{array}$ & $\begin{array}{c}\text { Neg } \\
0.26 \mathrm{~ns} \\
\end{array}$ & $\begin{array}{c}0.42 \\
\mathrm{~ns}\end{array}$ & $2.55 \mathrm{~ns}$ \\
\hline Sun and bathing & $\begin{array}{l}\mathrm{Neg} \\
1.17 \mathrm{~ns}\end{array}$ & $\begin{array}{c}\mathrm{Neg} \\
0.04 \mathrm{~ns}\end{array}$ & $1.22 \mathrm{~ns}$ & $0.60 \mathrm{~ns}$ & $\begin{array}{l}\mathrm{Neg} \\
2.94 \mathrm{~ns}\end{array}$ & $1.06 \mathrm{~ns}$ & $\begin{array}{c}2.82 \\
\text { ns }\end{array}$ & $0.53 \mathrm{~ns}$ \\
\hline Gardening and culture & $0.15 \mathrm{~ns}$ & $2.31 \mathrm{~ns}$ & $2.98 \mathrm{~ns}$ & $0.17 \mathrm{~ns}$ & $\begin{array}{c}7.08 \\
p<0.05\end{array}$ & $\begin{array}{c}8.27 \\
p<0.01\end{array}$ & $\begin{array}{c}4.40 \\
p<0.05\end{array}$ & $\begin{array}{c}7.04 \\
p<0.01\end{array}$ \\
\hline Winter sport & $\begin{array}{c}5.12 \\
p<0.05\end{array}$ & $0.46 \mathrm{~ns}$ & $\begin{array}{c}4.46 \\
p<0.05\end{array}$ & $2.98 \mathrm{~ns}$ & $2.23 \mathrm{~ns}$ & $2.84 \mathrm{~ns}$ & $\begin{array}{c}10.85 \\
p<0.01\end{array}$ & $1.67 \mathrm{~ns}$ \\
\hline Boating and view & $0.47 \mathrm{~ns}$ & $2.18 \mathrm{~ns}$ & $\begin{array}{c}5.02 \\
p<0.05\end{array}$ & $1.39 \mathrm{~ns}$ & $0.20 \mathrm{~ns}$ & $0.88 \mathrm{~ns}$ & $3.83 \mathrm{~ns}$ & $1.37 \mathrm{~ns}$ \\
\hline $\begin{array}{c}\text { Individual experiences } \\
\text { in nature } \\
\end{array}$ & $\begin{array}{c}4.49 \\
p<0.05\end{array}$ & $1.40 \mathrm{~ns}$ & $\begin{array}{c}5.85 \\
p<0.05\end{array}$ & $3.01 \mathrm{~ns}$ & $\begin{array}{c}6.39 \\
p<0.05\end{array}$ & $1.76 \mathrm{~ns}$ & $\begin{array}{c}12.80 \\
\mathrm{p}<0.001\end{array}$ & $\begin{array}{c}4.75 \\
p<0.05\end{array}$ \\
\hline $\begin{array}{l}\text { Horseback riding and } \\
\text { golf }\end{array}$ & $0.13 \mathrm{~ns}$ & $0.40 \mathrm{~ns}$ & $0.07 \mathrm{~ns}$ & $2.55 \mathrm{~ns}$ & $2.19 \mathrm{~ns}$ & $0.44 \mathrm{~ns}$ & $\begin{array}{c}0.01 \\
\text { ns }\end{array}$ & $0.01 \mathrm{~ns}$ \\
\hline Taking walks in nature & $0.71 \mathrm{~ns}$ & $\begin{array}{c}4.69 \\
p<0.05\end{array}$ & $\begin{array}{c}10.53 \\
p<0.01\end{array}$ & $\begin{array}{c}11.59 \\
p<0.01\end{array}$ & $0.01 \mathrm{~ns}$ & $1.54 \mathrm{~ns}$ & $\begin{array}{c}1.19 \\
\mathrm{~ns}\end{array}$ & $2.45 \mathrm{~ns}$ \\
\hline Jogging and cycling & $0.10 \mathrm{~ns}$ & $0.28 \mathrm{~ns}$ & $2.15 \mathrm{~ns}$ & $0.00 \mathrm{~ns}$ & $\begin{array}{l}\text { Neg } \\
0.33 \mathrm{~ns}\end{array}$ & $\begin{array}{c}\mathrm{Neg} \\
0.70 \mathrm{~ns}\end{array}$ & $\begin{array}{c}0.34 \\
\mathrm{~ns}\end{array}$ & $\begin{array}{l}\mathrm{Neg} \\
0.21 \mathrm{~ns}\end{array}$ \\
\hline
\end{tabular}

ANOVA, Type III. Model: LS (outcome) =activity type $1-10$ (exposure) SES and Sex. Number of observations 1,325 (all) and 823 (moved). 


\section{Appendix: Referred questions from the questionnaire}

A. How often have you visited these areas in the past twelve months?

1. Natural area with

$$
>3 \text { times/week 1-3 times/week 1-3 times/month 1-6 times/year Never }
$$

facilities for outdoor

activities, such as

parking places, marked

trails, and/or barbecue

$\begin{array}{lllll}\mathrm{O} & \mathrm{O} & \mathrm{O} & \mathrm{O} & \mathrm{O}\end{array}$

2. Natural area without

facilities for outdoor

recreation

at the lake or sea

$\mathrm{O}$

$\mathrm{O}$

$\mathrm{O}$

$\mathrm{O}$

$\mathrm{O}$

4. Open water, accessible

by boat or canoe

$\mathrm{O}$

$\mathrm{O}$

$\mathrm{O}$

$\mathrm{O}$

$\mathrm{O}$

5. Sea beach or

Archipelago

$\mathrm{O}$

$\mathrm{O}$

$\mathrm{O}$

$\mathrm{O}$

$\mathrm{O}$

B. Have you practised any of the following outdoor activities in the past 12 months? If yes, how often?

$$
>3 \text { times/week 1-3 times/week 1-3 times/month 1-6 times/year }
$$

1. Walking/rambling
2. Jogging
3. Cross-country skiing
4. Downhill skiing
5. Picking berries
6. Picking mushrooms
7. Boating
8. Fishing
9. Hunting
10. Golf
11. Horseback riding
12. Picnic/barbecue
13. Hiking and spending
the night in a tent
14. Bathing in the lake
or sea

or sea

$\mathrm{O}$

$\mathrm{O}$

O

O

$\mathrm{O}$

$\mathrm{O}$

$\mathrm{O}$

$\mathrm{O}$

$\mathrm{O}$

O

$\mathrm{O}$

O

$\mathrm{O}$

O

O

$\mathrm{O}$

O

$\mathrm{O}$

$\mathrm{O}$

$\mathrm{O}$

$\mathrm{O}$

$\mathrm{O}$

$\mathrm{O}$

$\mathrm{O}$

O

$\mathrm{O}$

$\mathrm{O}$

$\mathrm{O}$

$\mathrm{O}$

$\mathrm{O}$

O

$\mathrm{O}$

O

O

$\mathrm{O}$

$\mathrm{O}$

$\mathrm{O}$

$\mathrm{O}$

$\mathrm{O}$

O

O

O

$\mathrm{O}$

O

and plants

17. Enjoying cultural

environments

18. Cycling

19. Taking photos

20. Looking at the view

21. Skating

22. Sunbathing

23. Outing with the dog

24. Outings with family and friends

25. Resting and

relaxing

26. Gardening

27. Going out to be

by myself

28. Going out and having

a look at people
O

$\mathrm{O}$

$\mathrm{O}$

O

$\mathrm{O}$

$\mathrm{O}$

O

$\mathrm{O}$

$\mathrm{O}$

$\mathrm{O}$

$\mathrm{O}$

$\mathrm{O}$

$\mathrm{O}$

O

$\mathrm{O}$

$\mathrm{O}$

\section{$\mathrm{O}$}

$\mathrm{O}$

$\mathrm{O}$

$\mathrm{O}$

$\mathrm{O}$

$\mathrm{O}$

$\mathrm{O}$

O

$\mathrm{O}$

O

O

O

O

O

$\mathrm{O}$

O

O

O

O

O
O

O

O

$\mathrm{O}$

$\mathrm{O}$

O

O

O

O

O

O

O

O

O

O

O

O

O

O

O

O

O

O

O

O

O

O 
C. During the past 12 months, how often have you suffered from:

$\begin{array}{ccccccc}\begin{array}{c}\text { Never } \\ \text { occasionally }\end{array} & \begin{array}{c}\text { At most } \\ \text { once } \\ \text { quarterly }\end{array} & \begin{array}{c}\text { At most } \\ \text { once } \\ \text { monthly }\end{array} & \begin{array}{c}\text { At most } \\ \text { once } \\ \text { a fortnight }\end{array} & \begin{array}{c}\text { At most } \\ \text { once } \\ \text { weekly }\end{array} & \begin{array}{c}\text { Practically } \\ \text { every } \\ \text { day }\end{array} \\ \mathrm{O} & \mathrm{O} & \mathrm{O} & \mathrm{O} & \mathrm{O} & \mathrm{O} & \mathrm{O} \\ \mathrm{O} & \mathrm{O} & \mathrm{O} & \mathrm{O} & \mathrm{O} & \mathrm{O} & \mathrm{O} \\ \mathrm{O} & \mathrm{O} & \mathrm{O} & \mathrm{O} & \mathrm{O} & \mathrm{O} & \mathrm{O} \\ \mathrm{O} & \mathrm{O} & \mathrm{O} & \mathrm{O} & \mathrm{O} & \mathrm{O} & \mathrm{O} \\ \mathrm{O} & \mathrm{O} & \mathrm{O} & \mathrm{O} & \mathrm{O} & \mathrm{O} & \mathrm{O} \\ \mathrm{O} & \mathrm{O} & \mathrm{O} & \mathrm{O} & \mathrm{O} & \mathrm{O} & \mathrm{O} \\ \mathrm{O} & \mathrm{O} & \mathrm{O} & \mathrm{O} & \mathrm{O} & \mathrm{O} & \mathrm{O}\end{array}$

1. A cold (viral infection)

2. Strong headache

3. Irritation

4. Stress

5. Fatigue

6. Backache

7. Pain in the nape of the neck
O

$\mathrm{O}$

D. How long do you, on average, stay in the recreation area per visit?
4. 2-3 hours;
5. $>3$ hours
1. 15-30 minutes;
2. 30-60 minutes;
3. 1-2 hours; 